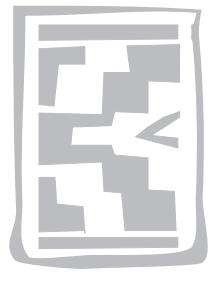

\title{
Molecular characterization of SAT-2 foot-and-mouth disease virus isolates obtained from cattle during a four-month period in 2001 in Limpopo Province, South Africa
}

\author{
B.S. PHOLOGANE ${ }^{1,2 \dagger}{ }^{2}$, R.M. DWARKA ${ }^{1}$, D.T. HAYDON ${ }^{3}$, L.J. GERBER ${ }^{2}$ and W. VOSLOO ${ }^{1,4 *}$
}

\begin{abstract}
PHOLOGANE, B.S, DWARKA, R.M, HAYDON, D.T., GERBER, L.J. \& VOSLOO, W. 2008. Molecular characterization of SAT-2 foot-and-mouth disease virus isolates obtained from cattle during a fourmonth period in 2001 in Limpopo Province, South Africa. Onderstepoort Journal of Veterinary Research, 75:267-277

Foot-and-mouth disease (FMD) is an acute, highly contagious viral infection of domestic and wild cloven-hoofed animals. The virus is a single-stranded RNA virus that has a high rate of nucleotide mutation and amino acid substitution. In southern Africa the South African Territories (SAT) 1-3 serotypes of FMD virus are maintained by large numbers of African buffaloes (Syncerus caffer), which provide a potential source of infection for domestic livestock and wild animals.

During February 2001, an outbreak of SAT-2 was recorded in cattle in the FMD control zone of South Africa, adjacent to the Kruger National Park (KNP). They had not been vaccinated against the disease since they form the buffer between the vaccination and free zones but in the face of the outbreak, they were vaccinated as part of the control measures to contain the disease. The virus was, however, isolated from some of them on several occasions up to May 2001. These isolates were characterized to determine the rate of genetic change in the main antigenic determinant, the $1 \mathrm{D} / 2 \mathrm{~A}$ gene. Nucleotide substitutions at 12 different sites were identified of which five led to amino acid changes. Three of these occurred in known antigenic sites, viz. the GH-loop and C-terminal part of the protein, and two of these have previously been shown to be subject to positive selection. Likelihood models indicated that the ratio of non-synonymous to synonymous changes among the outbreak sequences recovered from cattle was four times higher than among comparable sequences isolated from wildlife, suggesting that the virus may be under greater selective pressure during rapid transmission events.
\end{abstract}

Keywords: 1D (VP1) gene, cattle, foot-and-mouth disease, mutation rate, SAT-2

* Author to whom correspondence is to be directed. E-mail: vosloow@arc.agric.za

1 Agricultural Research Council, Onderstepoort Veterinary Institute, Exotic Diseases Division, Private Bag X05, Onderstepoort, 0110 South Africa

2 Department of Biomedical Science, Tshwane University of Technology, Private Bag X680, Pretoria, 0001 South Africa

3 Division of Environmental and Evolutionary Biology, University of Glasgow, Glasgow, G12 8QQ, UK

4 Department of Veterinary Tropical Diseases, Faculty of Veterinary Science, University of Pretoria, Private Bag X04, Onderstepoort, 0110 South Africa

$\dagger$ Deceased

Accepted for publication 2 July 2008-Editor

\section{INTRODUCTION}

Foot-and-mouth disease (FMD) is an acute, highly contagious viral infection of domestic and wild cloven-hoofed animals. Although mortality in adult animals is generally low, the production losses when intensively farmed livestock are infected can be significant. The aetiological agent of this disease, the foot-and-mouth disease virus (FMDV), belongs to the Aphthovirus genus of the Picornaviridae family. The virion consists of an icosahedral shell composed of 60 copies each of four structural proteins, VP1, VP2, VP3 and VP4 surrounding a singlestranded positive-sense RNA genome of approxi- 
mately 8500 nucleotides. Seven immunologically distinct serotypes (A, O, C, SAT-1, SAT-2, SAT-3 and Asia 1) have been identified, of which the South African Territories (SAT) types 1-3, are endemic in sub-Saharan Africa (Brooksby 1982). Historically, the SAT-2 serotype has been responsible for almost half of FMD outbreaks in domestic animals in southern Africa (Thomson \& Bastos 2004).

Eradication of the disease in sub-Saharan Africa is not possible owing to the presence of large numbers of free-living African buffaloes (Syncerus caffer), which are efficient maintenance hosts for the SAT types of FMDV and provide a potential source of infection for domestic livestock and wild animals (Thomson \& Bastos 2004; Vosloo \& Thomson 2004). These viruses can persist in an individual buffalo and in an isolated herd for at least 5 and 24 years, respectively (Condy, Hedger, Hamblin \& Barnett 1985).

The use of fencing to separate buffaloes and livestock as well as vaccination of cattle with viruses that are antigenically closely related to those carried by nearby buffalo form an integral part of FMD control in southern African countries (Hunter 1998; Brückner, Vosloo, Du Plessis, Kloeck, Connoway, Ekron, Weaver, Dickason, Schreuder, Marais \& Mogajane 2002). Despite these control measures, outbreaks of FMD do occur if some of the control measures are compromised, one of which, the SAT2 outbreak reported here, occurred in 2001 on farms in the Limpopo Province adjacent to the Kruger National Park (KNP), home to free-ranging, infected African buffaloes.

The disease remains a major economic concern for the livestock industry in many developing countries and a continued threat to countries that are disease free due to its potential negative impact on trade in agricultural products. Thus, rapid identification of the serotypes of FMDV that are responsible for an outbreak is essential for selection of an appropriate emergency vaccine and to trace the origin and spread of an outbreak (Callens \& De Clercq 1997). Genetic characterization of outbreak strains is also important to determine if variants exist in the field, especially for the SAT types in which it has been shown that more significant genetic variation occurs compared to other serotypes (Bastos, Haydon, Forsberg, Knowles, Anderson, Bengis, Nel \& Thomson 2001; Bastos, Anderson, Bengis, Keet, Winterbach \& Thomson 2003a; Bastos, Haydon, Sangare, Boshoff, Edrich \& Thomson 2003b; Sahle, Dwarka, Venter \& Vosloo 2007; Sahle, Dwarka, Venter \& Vosloo 2007a, b).
Foot-and-mouth disease viral RNA consists of a single open reading frame flanked by two non-coding regions both predicted to exhibit complex secondary structures (Mason, Grubman \& Baxt 2003). Because RNA viruses lack proof-reading capacity, their genomes undergo high mutation rates, shown to be between $10^{-5}$ and $10^{-4}$ base mis-incorporations per nucleotide site per genome replication (Holland, Spindler, Horodyski, Grabeu, Nichol \& Vande Pol 1982; Drake 1993; Drake \& Holland 1999). This, together with a very short generation time, can result in as much as $0.5-1.5 \%$ of the genome changing each year (Haydon, Samuel \& Knowles 2001b). The analysis of RNA sequences from field isolates indicated that fixation of mutations occurs along the entire FMDV genome, but mutations are preferentially accumulated in structural regions, which are the targets of selective pressures (Martin, Nunez, Sobrino \&Dopazo 1998; Fares, Moya, Escarmis, Baranowski, Domingo \& Barrio 2001; Haydon, Bastos, Samuel \& Knowles 2001a).

The high antigenic diversity of FMDV stems from its extreme genetic heterogeneity (Mateu, Martinez, Rocha, Andreu, Parejo, Giralt, Sobrino \& Domingo 1989). Antigenic variants can be selected for in immune or partially immune hosts (Gebauer, De la Torre, Gomes, Maten, Barahona, Tiraboshi, Bergman, De Mello \& Domingo 1988), although Diez, Mateu \& Domingo (1989) reported that antigenic variants may accumulate over time even in the absence of antibody selection. Studies have shown that cattle and buffalo carriers (subclinically infected animals) may be a significant source of genetic variation (Salt, Samuel \& Kitching 1996; Vosloo, Bastos, Kirkbride, Esterhuysen, Janse van Rensburg, Bengis, Keet \& Thomson 1996; Vosloo, De Klerk, Boshoff, Botha, Dwarka, Keet \& Haydon 2007). In particular, capsid protein VP1, encoded by the 1D gene, greatly contributes to the antigenicity of FMDV (Mateu et al. 1989; Mateu, Camarero, Giralt, Andreu \& Domingo 1995) due to the existence of an immuno-dominant site, located between beta-strands $G$ and $\mathrm{H}$ (the G-H loop) of VP1 which also acts as the cell receptor recognition site (Kitson, McCahon \& Belsham 1990). Other sites on the capsid involving VP2 and VP3 also play a role in the antigenic characteristics of the virus (Stave, Card, Morgan \& Vakharia 1988; Kitson et al. 1990).

During February 2001 an FMD outbreak was detected in cattle in the buffer zone in Limpopo Province, Republic of South Africa affecting various dip tanks in the communal farming district. The outbreak followed severe flooding in the area that damaged 
the game fence surrounding the KNP and buffaloes were observed on the communal farms. This study concerned the investigation of the genetic variation accumulating in the $1 \mathrm{D}$ gene among 11 SAT-2 isolates obtained from a single outbreak over 111 days. Sequencing of the full-length 1D gene of these SAT-2 outbreak strains enabled us to determine the position of substitutions in the main antigenic determinant. In response to the outbreak, immediate widespread vaccination of cattle herds was conducted. In order to examine whether vaccination resulted in a change in selective pressures on the virus the ratio of non-synonymous to synonymous changes among the outbreak sequences were compared with those from closely related strains isolated from wildlife in the adjoining KNP.

\section{MATERIALS AND METHODS}

\section{Viruses included in this study}

Eleven viruses were isolated from bovine epithelial tissue samples taken from clinically affected animals on various farms involved in the SAT-2 outbreak over 111 days (Table 1). These samples were first propagated on primary pig kidney (PK) cells and, if necessary, passaged on IB-RS-2 (Instituto Biologico Rim Suino) cells. Once positive cultures were obtained, the viruses were stored in glycerol at $-70^{\circ} \mathrm{C}$ for further characterization. Twelve SAT-2 1D sequences were selected from previous publications for phylogenetic and other analysis. Table 1 summarizes all relevant information regarding the viruses used in this study.

\section{RNA extraction, cDNA synthesis and genomic amplification}

Genomic RNA was extracted from cultured viruses by a modified silica/guanidinium thiocyanate nucleic acid extraction method (Boom, Sol, Salimans, Jansen, Wertheim-Van Dillen \& Van der Noordaa 1990) and reverse transcribed using AMV-RT (Promega) and the $2 A / B$ junction primer, $\mathrm{P} 1$, of Beck \& Strohmaier (1987) as described by Bastos (1998).

Genomic amplification of the 1D gene was performed using a forward primer binding within the $1 \mathrm{C}$ gene (VP3) termed VP3-AB (5' CAC TGC TAC CAC TCR GAG TG 3') (Bastos et al. 2003b) and a reverse primer, $\mathrm{P} 1$ (5' GAA GGG CCC AGG GTT GGA CTC 3') which is complimentary to the highly conserved 2A/B junction site (Beck \& Strohmaier 1987 ), resulting in a product of approximately 880 bp. PCR was performed in a $50 \mu \ell$ volume in the presence of $3 \mu \ell \mathrm{cDNA}, 200 \mu \mathrm{M}$ dNTPs, $25 \mathrm{pmol}$ of each primer, $1 \times$ Taq buffer (Roche) and $2.5 \mathrm{U}$ of Taq polymerase (Roche). Thermal cycling profile included an initial denaturation step at $96^{\circ} \mathrm{C}$ for 1 min, followed by 30 cycles of denaturation at $96^{\circ} \mathrm{C}$ for $20 \mathrm{~s}$, annealing at $56^{\circ} \mathrm{C}$ for $30 \mathrm{~s}$ and extension at $70^{\circ} \mathrm{C}$ for $30 \mathrm{~s}$.

\section{PCR product purification and nucleotide sequence determination}

The PCR products of $880 \mathrm{bp}$ were excised from the $1.5 \%$ agarose gel and purified using the QIAquick Gel Extraction Kit (Qiagen). Sequencing of the full length 1D gene (648 bp) was performed using the Big Dye ${ }^{\circledR}$ version 3.1 cycle sequencing ready reaction kit and the $\mathrm{ABI}$ Prism 310 Genetic Analyser (Applied Biosystems). Two independent cycle sequencing reactions were performed per sample using the sense and anti-sense primers utilized in the PCR.

\section{Phylogenetic analysis}

Nucleotide sequences were trimmed to correspond to the full length 1D gene (648 bp) and six nucleotides of the 2A gene of all SAT-2 outbreak strains and aligned with published sequences (obtained from Genbank, Table 1) using the DAPSA program (Harley 2001). Phylogenetic trees were constructed using maximum likelihood methods (Swofford 2001) assuming an HKY85 model (Hasegawa, Kishino \& Yano 1985) of nucleotide substitution with rate heterogeneity. Support for the phylogenetic groups within the tree was estimated from 1000 bootstrap re-samples using the neighbour-joining method (Swofford 2001) with the same model of nucleotide substitution.

Statistical parsimony (implemented in the program TCS [Clement, Posada \& Crandell 2000]) was utilized to reconstruct the sequence of mutations throughout the course of the outbreak. This parsimony-based algorithm outputs a rooted network indicating likely haplotype transitions. The underlying population genetic algorithm on which the statistical basis of the output is determined is complex and described in detail elsewhere (Templeton, Crandall \& Sing 1992) and is particularly suited for application to very closely related sequences.

The ratio of non-synonymous to synonymous substitutions $\left(d_{n} / d_{s}\right)$ for the sequences detailed in Table 1 was calculated using the program Codeml (Yang 1997) which approximates the $d_{n} / d_{s}$ ratio over the estimated phylogeny. Different $d_{n} / d_{s}$ ratios over dif- 
Molecular characterization of SAT-2 foot-and-mouth disease virus isolates obtained from cattle in South Africa

TABLE 1 Summary of SAT-2 serotype isolates included in this study

\begin{tabular}{|c|c|c|c|c|c|c|c|}
\hline $\begin{array}{l}\text { Virus } \\
\text { designation }\end{array}$ & $\begin{array}{l}\text { Country } \\
\text { of origin }\end{array}$ & $\begin{array}{l}\text { Date of } \\
\text { sampling }\end{array}$ & Place of origin & Grid reference & Species & $\begin{array}{l}\text { GenBank } \\
\text { accession } \\
\text { no. }\end{array}$ & $\begin{array}{l}\text { Days } \\
\text { post } \\
\text { outbreak }\end{array}$ \\
\hline $\mathrm{SAR} / 1 / 01^{\star}$ & RSA & 01/02/2001 & Orinoco DT, LP & $31^{\circ} 05^{\prime} \mathrm{E}-24^{\circ} 45^{\prime} \mathrm{S}$ & Bov & AY442903 & 1 \\
\hline $\mathrm{SAR} / 2 / 01^{\bullet}$ & RSA & 01/02/2001 & Orinoco DT, LP & $31^{\circ} 05^{\prime} \mathrm{E}-24^{\circ} 45^{\prime} \mathrm{S}$ & Bov & AY442904 & 1 \\
\hline SAR/3/01 • & RSA & 01/02/2001 & Orinoco DT, LP & $31^{\circ} 05^{\prime} \mathrm{E}-24^{\circ} 45^{\prime} \mathrm{S}$ & Bov & AY442905 & 1 \\
\hline $\mathrm{SAR} / 4 / 01^{\bullet}$ & RSA & 01/02/2001 & Orinoco DT, LP & $31^{\circ} 05^{\prime} \mathrm{E}-24^{\circ} 45^{\prime} \mathrm{S}$ & Bov & AY442906 & 1 \\
\hline SAR/5/01* & RSA & 06/02/2001 & Orinoco DT, LP & $31^{\circ} 05^{\prime} \mathrm{E}-24^{\circ} 45^{\prime} \mathrm{S}$ & Bov & AY442907 & 6 \\
\hline SAR/6/01 & RSA & 04/02/2001 & Newington, LP & $31^{\circ} 18^{\prime} \mathrm{E}-24^{\circ} 48^{\prime} \mathrm{S}$ & Bov & AY442908 & 4 \\
\hline $\mathrm{SAR} / 7 / 01^{\wedge}$ & RSA & 05/02/2001 & Dwarsloop, LP & $31^{\circ} 06^{\prime} \mathrm{E}-24^{\circ} 47^{\prime} \mathrm{S}$ & Bov & AY442909 & 5 \\
\hline SAR/8/01 & RSA & 05/02/2001 & Dwarsloop, LP & $31^{\circ} 06^{\prime} \mathrm{E}-24^{\circ} 47^{\prime} \mathrm{S}$ & Bov & AY442910 & 5 \\
\hline SAR/9/01 & RSA & 05/02/2001 & Dwarsloop, LP & 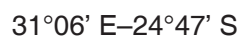 & Bov & AY442911 & 5 \\
\hline SAR/10/01^ & RSA & $22 / 05 / 2001$ & Craigieburn, LP & $30^{\circ} 58^{\prime} \mathrm{E}-24^{\circ} 40^{\prime} \mathrm{S}$ & Bov & AY442912 & 111 \\
\hline $\mathrm{SAR} / 11 / 01^{\diamond}$ & RSA & $22 / 05 / 2001$ & Craigieburn, LP & $30^{\circ} 58^{\prime} \mathrm{E}-24^{\circ} 40^{\prime} \mathrm{S}$ & Bov & AY442913 & 111 \\
\hline $\mathrm{KNP} / 18 / 95$ & RSA & 1995 & Mondzweni & $31^{\circ} 38^{\prime} \mathrm{E}-24^{\circ} 34^{\prime} \mathrm{S}$ & Buf & AF367118* & - \\
\hline $\mathrm{KNP} / 31 / 95$ & RSA & 1995 & Mondzweni & 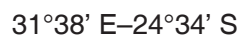 & Buf & AF367119* & - \\
\hline $\mathrm{KNP} / 19 / 89$ & RSA & 1989 & Ripape & $31^{\circ} 37^{\prime} \mathrm{E}-24^{\circ} 44^{\prime} \mathrm{S}$ & Buf & AF367110* & - \\
\hline $\mathrm{KNP} / 183 / 91$ & RSA & 1991 & Water Affairs weir & $31^{\circ} 56^{\prime}$ E-250. & Buf & AF367112* & - \\
\hline $\mathrm{KNP} / 32 / 92$ & RSA & 1992 & $\begin{array}{l}\text { Boyela } \\
\text { Vlakteplaas }\end{array}$ & $31^{\circ} 17^{\prime} \mathrm{E}-22^{\circ} 54^{\prime} \mathrm{S}$ & Buf & AF367115* & - \\
\hline $\mathrm{KNP} / 18 / 88$ & RSA & 1988 & Orpen gate & 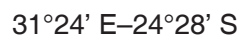 & Imp & AF367138* & - \\
\hline $\mathrm{KNP} / 19 / 88$ & RSA & 1988 & Rabelais Dam & $31^{\circ} 30^{\prime} \mathrm{E}-24^{\circ} 27^{\prime} \mathrm{S}$ & Imp & AF367106* & - \\
\hline $\mathrm{KNP} / 20 / 88$ & RSA & 1988 & Timbavati River & $31^{\circ} 28^{\prime} \mathrm{E}-24^{\circ} 26^{\prime} \mathrm{S}$ & Imp & AF367107* & - \\
\hline $\mathrm{ZIM} / 267 / 98$ & Zim & 1998 & Chizarira & $28^{\circ} 00^{\prime} \mathrm{E}-17^{\circ} 47^{\prime} \mathrm{S}$ & Buf & AF367130* & - \\
\hline ZAM/7/96 & Zam & 1996 & Mulanga & $25^{\circ} 30^{\prime} \mathrm{E}-17^{\circ} 10^{\prime} \mathrm{S}$ & Buf & AF367120* & - \\
\hline ZAM/10/96 & Zam & 1996 & Mulanga & $25^{\circ} 30^{\prime} \mathrm{E}-17^{\circ} 10^{\prime} \mathrm{S}$ & Buf & AF367121* & - \\
\hline ВОТ/18/98 & Bot & 1998 & Nxaraga & $23^{\circ} 15^{\prime} \mathrm{E}-19^{\circ} 40^{\prime} \mathrm{S}$ & Buf & AF367123* & - \\
\hline
\end{tabular}

RSA = Republic of South Africa; LP = Limpopo Province; Zim = Zimbabwe; Zam = Zambia; Bot = Botswana; Bov = bovine; Buf = buffalo; Imp = impala; - = not applicable; passage history of viruses (PK = primary pig kidney cells, RS = IBRS-2 cell line): ^ ${ }^{\star} P K 1$, $\mathrm{RS} 1 ; \bullet \mathrm{PK} 1 ;{ }^{\bullet} \mathrm{PK} 1, \mathrm{RS} 2$

* Bastos et al. 2003b

ferent parts of the tree were estimated. Because the viruses in this study were replicating in vaccinated hosts, the hypothesis that they might be under more intense selective pressure than viruses in the rest of the phylogeny was tested and therefore two $d_{n} / d_{s}$ ratios were fitted: one to non-outbreak strains, and the other to the monophyletic group constituting the outbreak strains (indicated in Fig. 1). Since the simpler model is nested within the more complex model, a likelihood-ratio rest (LRT) could be used to de- termine the level of support for the more complex model.

\section{RESULTS}

\section{Phylogenetic analysis}

The maximum-likelihood tree showed that the 11 outbreak sequences (SAR/1/01 to SAR/11/01) were all closely related to each other and grouped in a 
R.M. PHOLOGANE et al.

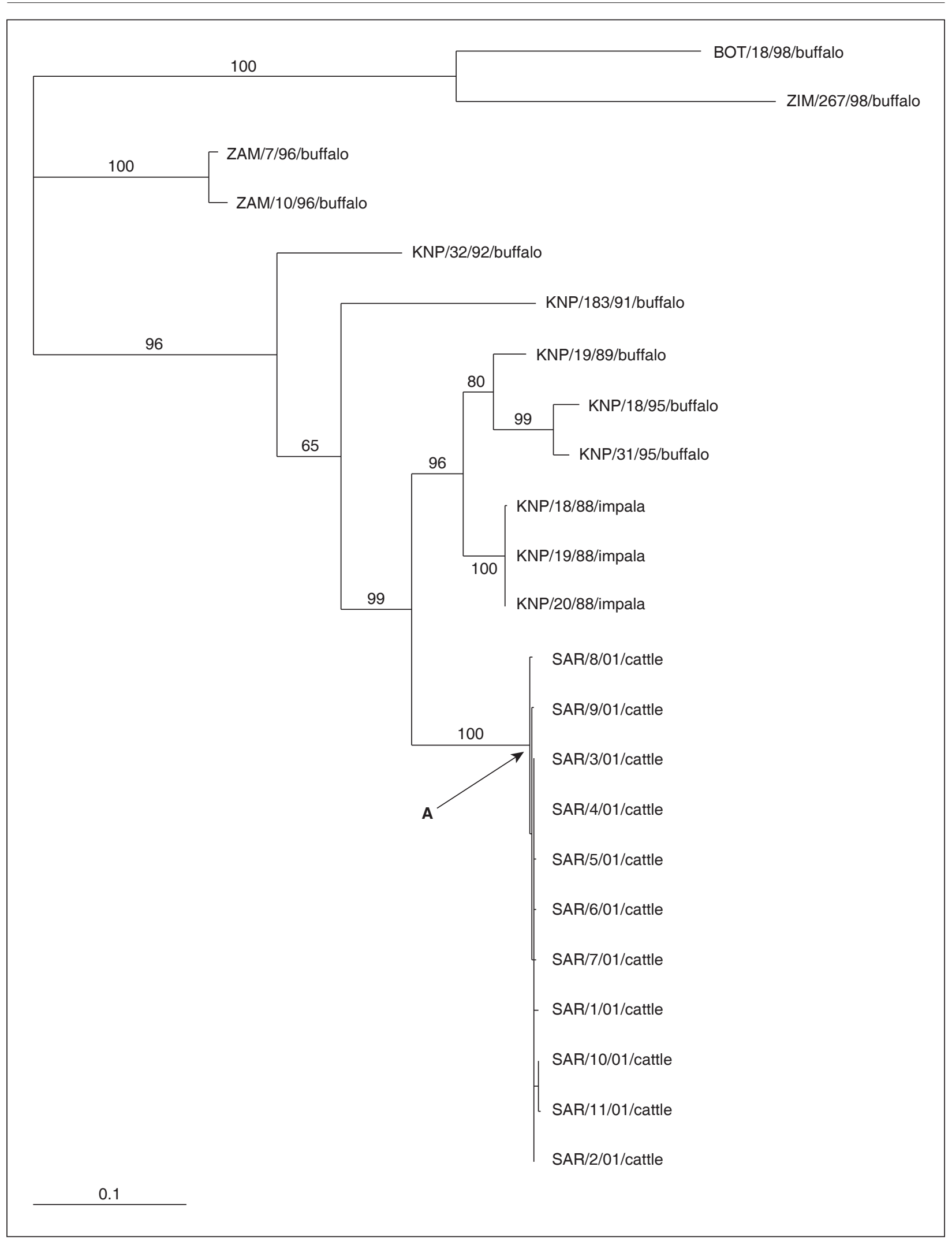

FIG. 1 The maximum likelihood phylogeny of the outbreak sequences and a number of closely related sequences from wildlife obtained in the KNP, Zimbabwe, Botswana and Zambia. Levels of bootstrap support (estimated using the neighbor-joining method) are indicated on the branches. The 'A' indicates the position downstream from which a different $d_{n} / d_{s}$ ratio was fitted to the rest of the tree 
single cluster with $100 \%$ bootstrap support (Fig. 1). The outbreak isolates grouped with viruses previously obtained from the KNP during an outbreak in impalas in 1988 (KNP/18-20/88) and isolates obtained from buffaloes in the park between 1989 and 1995 (KNP/19/89, KNP/18/95 and KNP/31/95) (12$13 \%$ nucleotide differences). This cluster was supported by $99 \%$ bootstrap. The buffalo isolates from Zambia, Zimbabwe and Botswana grouped according to topotype patterns previously observed for SAT-2 (Fig. 1; Bastos et al. 2003b). The estimated transition:transversion ratio for this set of sequences was 2.51:1, and the shape parameter for the $\Upsilon$-distribution governing rate heterogeneity was estimated to be 0.27 .

\section{Mutation analysis}

The coding region included in the analysis contained 648 nucleotides from the 1D/2A gene, translated into 216 amino acid residues (214 aa 1D and 2 aa of $2 A$, Fig. 2). Three of the initial isolates (SAR/2$4 / 01$ ) had $100 \%$ identical nucleotide sequences and were assumed to represent the ancestral state. On the same day and the same farm, Orinoco, SAR/1/01 was isolated that differed by $0.309 \%$ from the other isolates. On Day 4, SAR/6/01, isolated on the farm Newington, differed by $0.154 \%$, while the three Dwarsloop isolates (SAR/7-9/01) obtained at Day 5 differed by $0.154 \%, 0.463 \%$ and $0.309 \%$, respectively, from the original viruses. SAR/5/01 was iso-

\begin{tabular}{|c|c|c|c|c|c|c|c|c|}
\hline & 10 & 20 & 30 & 40 & 50 & 60 & 70 & 80 \\
\hline $\mathrm{SAR} / 2 / 01$ & TTSAGEGADV & VTTDPSTHGG & QVKEKRRMHT & DVAFVLDRET & HVHTNKTTFN & VDLMDTNSKT & LVGALLRAST & YYFCDLEIAC \\
\hline $\mathrm{SAR} / 1 / 01$ & $\ldots \ldots \ldots$ & $\ldots \ldots \ldots$ & $\ldots \ldots \ldots$ & $\ldots \ldots \ldots$ & $\ldots \ldots \ldots$ & $\ldots \ldots \ldots$ & $\ldots \ldots \ldots$ & $\ldots \ldots \ldots$ \\
\hline $\mathrm{SAR} / 3 / 01$ & $\ldots \ldots$ & $\ldots \ldots$ & $\ldots \ldots \ldots$ & $\ldots \ldots \ldots$ & $\ldots \ldots \ldots$ & $\ldots \ldots \ldots$ & $\ldots \ldots \ldots$ & $\ldots \ldots \ldots$ \\
\hline $\mathrm{SAR} / 4 / \mathrm{O} 1$ & $\ldots \ldots \ldots$ & $\ldots \ldots \ldots$ & $\ldots \ldots \ldots$ & $\ldots \ldots \ldots$ & $\ldots \ldots \ldots$ & $\ldots \ldots \ldots$ & $\ldots \ldots \ldots$ & $\ldots \ldots \ldots$ \\
\hline $\mathrm{SAR} / 5 / 01$ & $\ldots \ldots \ldots$ & $\ldots \ldots \ldots$ & $\ldots \ldots L \ldots$ & $\ldots \ldots \ldots$ & $\ldots \ldots \ldots$ & $\ldots \ldots \ldots$ & $\ldots \ldots \ldots$ & $\ldots \ldots \ldots$ \\
\hline $\mathrm{SAR} / 6 / 01$ & $\ldots \ldots \ldots$ & $\ldots \ldots \ldots$ & $\ldots \ldots \ldots$ & $\ldots \ldots \ldots$ & $\ldots \ldots \ldots$ & $\ldots \ldots \ldots$ & $\ldots \ldots \ldots$ & $\ldots \ldots \ldots$ \\
\hline $\mathrm{SAR} / 7 / 01$ & $\ldots \ldots \ldots$ & $\ldots \ldots \ldots$ & $\ldots \ldots \ldots$ & $\ldots \ldots \ldots$ & $\ldots \ldots \ldots$ & $\ldots \ldots \ldots$ & $\ldots \ldots \ldots$ & $\ldots \ldots \ldots$ \\
\hline $\mathrm{SAR} / 8 / 01$ & $\ldots \ldots \ldots$ & $\ldots \ldots \ldots$ & $\ldots \ldots \ldots$ & $\ldots \ldots \ldots$ & $\ldots \ldots \ldots$ & $\ldots \ldots \ldots$ & $\ldots \ldots \ldots$ & $\ldots \ldots \ldots$ \\
\hline $\mathrm{SAR} / 9 / 01$ & $\ldots \ldots \ldots$ & $\ldots \ldots \ldots$ & $\ldots \ldots \ldots$ & $\ldots \ldots \ldots$ & $\ldots \ldots \ldots$ & $\ldots \ldots \ldots$ & $\ldots \ldots \ldots$ & $\ldots \ldots \ldots$ \\
\hline $\mathrm{SAR} / 10 / 01$ & $\ldots \ldots \ldots$ & $\ldots \ldots \ldots$ & $\ldots \ldots \ldots$ & $\ldots \ldots \ldots$ & $\ldots \ldots \ldots$ & $\ldots \ldots \ldots$ & $\ldots \ldots \ldots$ & $\ldots \ldots \ldots$ \\
\hline \multirow[t]{2}{*}{$\mathrm{SAR} / 11 / 01$} & $\ldots \ldots$ & $\ldots \ldots$ & $\ldots \ldots \ldots$ & $\ldots \ldots \ldots$ & $\ldots \ldots \ldots$ & $\ldots \ldots \ldots$ & $\ldots \ldots \ldots$ & $\cdots \cdots \cdots$ \\
\hline & 90 & 100 & 110 & 120 & 130 & 140 & 150 & 160 \\
\hline $\mathrm{SAR} / 2 / 01$ & VGEHKRVYWQ & PNGAPRTTQL & GDNPMVFSNK & GVTREAVPYT & APHRLLSTVY & NGECKYTASV & TAIRGDRAVL & AAKYTNTKHT \\
\hline $\mathrm{SAR} / 1 / 01$ & $\ldots \ldots \ldots$ & $\ldots \ldots \ldots$ & $\ldots \ldots \ldots$ & $\ldots \ldots \ldots$ & $\ldots \ldots \ldots$ & ........ & $\ldots \ldots \ldots$ & $\ldots \ldots \ldots$ \\
\hline $\mathrm{SAR} / 3 / 01$ & $\ldots \ldots \ldots$ & $\ldots \ldots \ldots$ & $\ldots \ldots \ldots$ & $\ldots \ldots \ldots$ & $\ldots \ldots \ldots$ & $\ldots \ldots \ldots$ & $\ldots \ldots \ldots$ & $\ldots \ldots \ldots$ \\
\hline $\mathrm{SAR} / 4 / 01$ & $\ldots \ldots \ldots$ & $\ldots \ldots \ldots$ & $\ldots \ldots \ldots$ & $\ldots \ldots \ldots$ & $\ldots \ldots \ldots$ & $\ldots \ldots \ldots$ & $\ldots \ldots \ldots$ & $\ldots \ldots \ldots$ \\
\hline $\mathrm{SAR} / 5 / 01$ & $\ldots \ldots \ldots$ & $\ldots \ldots$ & $\ldots \ldots \ldots$ & $\ldots \ldots \ldots$ & $\ldots \ldots \ldots$ & $\ldots \ldots \ldots$ & $\ldots \ldots \ldots$ & $\ldots \ldots \ldots$ \\
\hline $\mathrm{SAR} / 6 / 01$ & $\ldots \ldots$ & $\ldots \ldots \ldots$ & $\ldots \ldots \ldots$ & $\cdots \cdots \cdots$ & $\ldots \ldots \ldots$ & $\ldots \ldots \ldots$ & $\ldots \ldots \ldots$ & $\ldots \ldots \ldots$ \\
\hline $\mathrm{SAR} / 7 / 01$ & $\ldots \ldots$ & $\ldots \ldots$ & $\ldots \ldots \ldots$ & $\ldots \ldots$ & $\cdots \cdots$ & $\ldots \ldots \ldots$ & $\ldots \ldots \ldots$ & $\ldots \ldots \ldots$ \\
\hline $\mathrm{SAR} / 8 / 01$ & $\ldots \ldots \ldots$ & $\ldots \ldots \ldots$ & $\ldots \ldots \ldots$ & $\ldots \ldots \ldots$ & $\ldots \ldots \ldots$ & $\ldots \ldots \ldots$ & $\ldots \ldots \ldots$ & $\ldots \ldots \ldots$ \\
\hline $\mathrm{SAR} / 9 / 01$ & $\ldots \ldots \ldots$ & $\ldots \ldots \ldots$ & $\ldots \ldots \ldots$ & $\ldots \ldots \ldots$ & $\ldots \ldots \ldots$ & $\ldots \ldots \ldots$ & $\ldots \ldots \ldots$ & $\ldots \ldots \ldots$ \\
\hline $\mathrm{SAR} / 10 / 01$ & $\ldots \ldots \ldots$ & $\ldots \ldots \ldots$ & $\ldots \ldots \ldots$ & $\ldots \ldots \ldots$ & $\ldots \ldots \ldots$ & $\ldots \ldots \ldots$ & $\ldots \ldots \ldots$ & $\ldots \ldots \ldots$ \\
\hline \multirow[t]{3}{*}{$\mathrm{SAR} / 11 / 01$} & $\ldots K \ldots \ldots$ & $\ldots \ldots \ldots$ & $\ldots \ldots \ldots$ & $\ldots \ldots$ & $\ldots \ldots$ & $\ldots \ldots \ldots$ & $\ldots \ldots$ & $\ldots \ldots \ldots$ \\
\hline & & & & & & $2 \mathrm{~A}$ & & \\
\hline & 170 & 180 & 190 & 200 & 210 & 215 & & \\
\hline $\mathrm{SAR} / 2 / 01$ & LPSTFNFGHV & TADASVDVYY & RMKRAELYCP & RPLLPAYDHA & NRDRFDAPIG & VEKQ LC & & \\
\hline $\mathrm{SAR} / 1 / 01$ & $\ldots \ldots \ldots$ & $\ldots \ldots \ldots$ & $\ldots \ldots \ldots$ & $\ldots \ldots \ldots$ & $\ldots \ldots \ldots$ & $\ldots \ldots$ & & \\
\hline $\mathrm{SAR} / 3 / 01$ & $\ldots \ldots \ldots$ & $\ldots \ldots \ldots$ & $\ldots \ldots \ldots$ & $\ldots \ldots \ldots$ & $\ldots \ldots \ldots$ & $\ldots \ldots$ & & \\
\hline $\mathrm{SAR} / 4 / \mathrm{O} 1$ & $\cdots \cdots$ & $\cdots \cdots$ & $\ldots \ldots \ldots$ & $\ldots \ldots$ & $\cdots \cdots$ & $\ldots \ldots$ & & \\
\hline $\mathrm{SAR} / 5 / 01$ & $\cdots \cdots \cdots$ & $\cdots \cdots$ & $\ldots \ldots \ldots$ & $\cdots \cdots \cdots$ & $\cdots \cdots \cdots$ & $\cdots \cdots$ & & \\
\hline $\mathrm{SAR} / 6 / 01$ & $\ldots \ldots$ & $\ldots \ldots$ & $\ldots \ldots \ldots$ & $\ldots \ldots \ldots$ & $s \ldots \ldots$ & $\ldots \ldots$ & & \\
\hline $\mathrm{SAR} / 7 / 01$ & $\ldots \ldots$ & $\ldots \ldots$ & $\ldots \ldots \ldots$ & $\ldots \ldots$ & $\ldots \ldots$ & A.... & & \\
\hline $\mathrm{SAR} / 8 / 01$ & $\ldots \ldots$ & $\ldots \ldots$ & $\ldots \ldots \ldots$ & $\cdots \cdots \cdots$ & $\cdots \cdots \cdots$ & $\cdots \cdots$ & & \\
\hline $\mathrm{SAR} / 9 / 01$ & $\ldots \ldots \ldots$ & $\ldots \ldots \ldots$ & $\cdots \cdots \cdots$ & $\cdots \cdots \cdots$ & $\cdots \cdots \cdots$ & $\cdots \cdots$ & & \\
\hline $\mathrm{SAR} / 10 / 01$ & $\cdots \cdots \cdots$ & $\cdots \cdots \cdots$ & $\cdots \cdots \cdots$ & $\cdots \cdots \cdots$ & $\cdots \cdots \cdots$ & $\cdots \cdots$ & & \\
\hline $\mathrm{SAR} / 11 / 01$ & $\cdots \cdots \cdots$ & $\ldots \ldots \ldots$ & $\ldots \ldots \ldots$ & $\ldots \ldots \ldots$ & $\cdots \cdots \cdots$ & $\cdots \cdots$ & & \\
\hline
\end{tabular}

FIG. 2 Sequence alignments of 216 amino acids corresponding to the 1D/2A gene of the 11 SAT-2 outbreak strains obtained during a single outbreak that affected various farms during 2001. Cell attachment site of the viruses (RGD), in the G-H loop is highlighted and underlined. ' ' indicates amino acids identical to SAR/2/01 
lated at Day 6 from Orinoco and similarly differed by $0.154 \%$. On Day 111 two isolates were obtained from Craigieburn and differed by $0.309 \%$ and $0.463 \%$ from the ancestral state.

The TCS analysis of the nucleotide sequences (Fig. 3 ) indicated that this divergence probably accumulated as a result of 12 independent mutations (11 in VP1 and 1 in the 2A gene). Five of these mutations resulted in non-synonymous amino acid changes: position 27: G-T, Arginine to Leucine (SAR/5/01); 83: G-A, Glutamic acid to Lysine (SAR/11/01); 135: A-G, Lysine to Glutamic acid (SAR/1/01); 201: A-G, Asparagine to Serine (SAR/6/01); and 211: T-C, Valine to Alanine $(S A R / 7 / 01)$. The latter three of these changes arose in known antigenic sites, the G-H loop (135) and the C-terminus region (201 to 211) (Kitson et al. 1990). Al these amino acid substitutions were due to nucleotide differences in the second position of the codon, except the change on amino acid position 135, which occurred in the fist position of the codon. None of the changes became fixed in isolates over time.

The TCS analysis (Fig. 3 ) shows that one variant (SAR/1/01) was present within the first 3 days of the outbreak together with a theoretical genotype not sampled. This latter variant was not isolated again and may have been a dead-end for this particular virus. The ancestral virus seemed to have spread to other farms. Between Days 4-110 five more variants were sampled of which three (SAR/5-7/01) resulted from three separate direct changes from the ancestral state, and two viruses (SAR/8-9/01) represented viruses arising from genotypes that were not sampled (Fig. 3). At Day 111 two viruses were isolated, one resulted from an absent genotype (SAR/10/01), while the last isolate (SAR/11/01) was

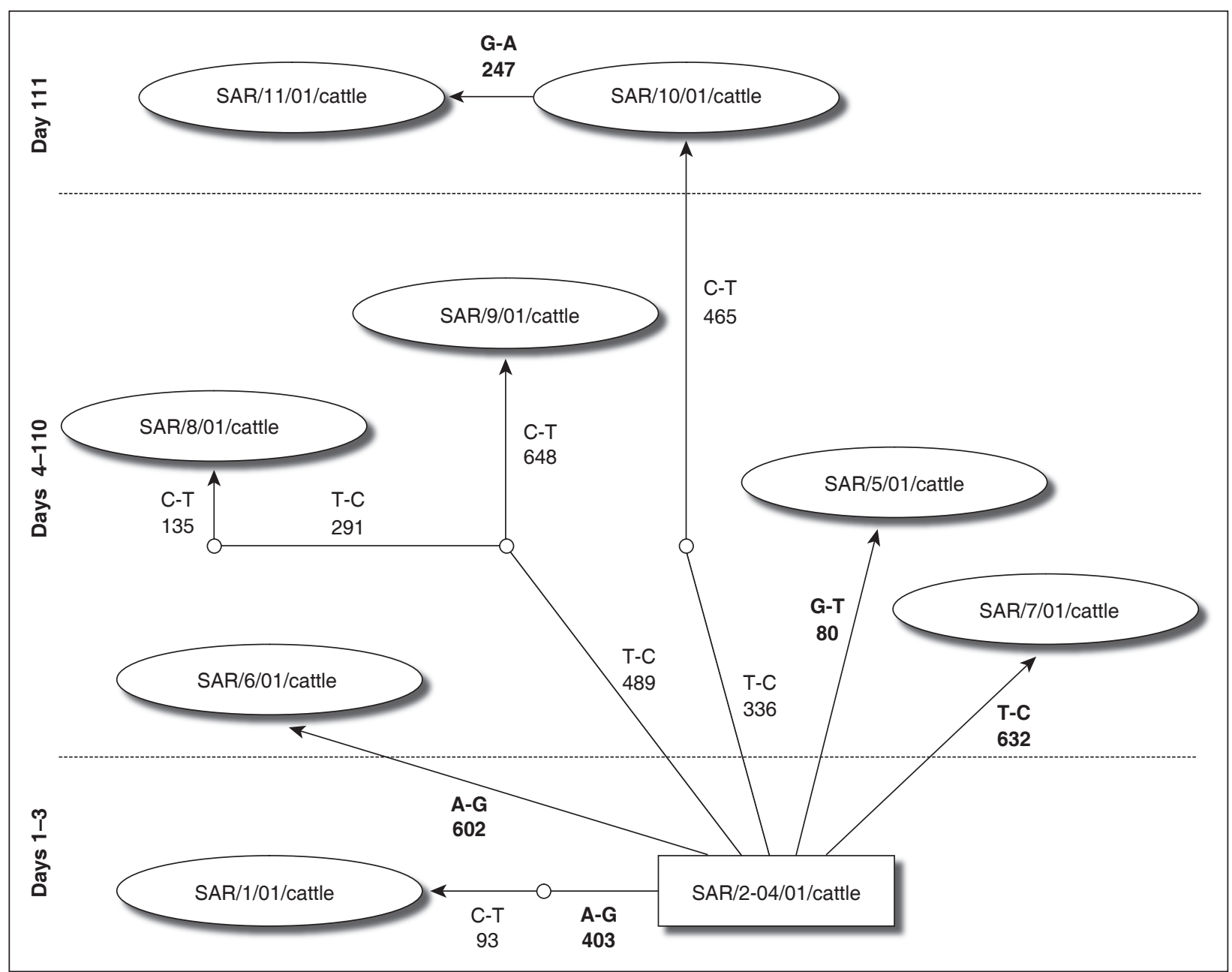

FIG. 3 The rooted cladogram supported by statistical parsimony in the program TCS. The square indicates the identified root of the genealogy. Small circles indicate genotypes that were not sampled. Nucleotide substitutions are labelled on the arrows (those in bold are non-synonymous). Where a genotype is removed from its putative ancestor by more than one mutational change, the order of these changes is unknown 
related to $S A R / 10 / 01$ and originated from a single difference between the two isolates.

The overall average $d_{n} / d_{s}$ ratio calculated in Codeml over the phylogeny shown in Fig. 1 was 0.070 , indicating strong purifying selection. When two $d_{n} / d_{s}$ ratios were fitted, one over the outbreak clade, and another for the rest of the tree, the $d_{n} / d_{s}$ ratio for the main tree declined to 0.066 , but increased to 0.264 in the outbreak clade. The LRT indicated that this more complex model was a significant improvement over the simpler model $\left(\chi^{2}=4.1, P<0.05\right)$ and suggested that the four-fold increase in the $d_{n} / d_{s}$ ratio in the outbreak clade should be regarded as significant.

\section{DISCUSSION}

In the case of an FMD outbreak, rapid identification of the serotypes of FMDV that are responsible for the outbreak is essential for selection of an appropriate emergency vaccine and helps to trace the origin and spread of the outbreak (Callens \& De Clercq 1997; Vosloo, Bastos \& Boshoff 2006) as well as wildlife movements (Vosloo, Bastos, Michel \& Thomson 2001). South Africa experienced an outbreak caused by the Pan-Asian serotype $O$ in 2000 (Sangare, Bastos, Marquardt, Venter, Vosloo \& Thomson 2001 ) that was introduced by the illegal use of swill as pig feed (Brückner et al. 2002). This serotype does not occur in the buffalo populations in southern Africa and is therefore exotic to the region and had to be eradicated with urgency. The outbreak was finally controlled by stamping out, vaccination using an imported vaccine of known efficacy to the outbreak strain and strict quarantine measures, resulting in severe financial losses to both commercial and small scale farmers in the area. Implementation of control measures depends on accurate genetic characterization of the virus strain responsible for an outbreak.

Phylogenetic analysis of the SAT-2 outbreak in 2001 revealed that all 11 virus samples collected from the infected premises clustered in one strongly supported clade, which was related to viruses isolated from buffaloes and impalas living in adjacent wildlife reserves, strongly suggesting that wildlife was the origin of the outbreak (Fig. 1). This clade has previously been shown to belong to a topotype that covers the geographical regions of north eastern South Africa (KNP), south eastern Zimbabwe and Mozambique (Bastos et al. 2003b). The same geographic areas form a topotype for SAT-1 (Bastos et al. 2001) and SAT-3 (Bastos et al. 2003b), re- spectively. The isolates from Zambia (ZAM/7/96 and $Z A M / 10 / 96)$ clustered together as did viruses from Botswana (BOT/18/98) and Zimbabwe (ZIM/267/98), in accordance with their previous description into two separate topotypes, albeit with overlapping distribution ranges (Bastos et al. 2003b). The KNP/ south Zimbabwe/Mozambique topotype differs significantly from other topotypes in the region and the clustering profile of the outbreak isolates within this southern topotype, together with the outbreak's proximity to the KNP, is a strong indication that the virus originated in the KNP. This hypothesis is supported by the observation that fencing, constructed to prevent the co-migration of wildlife and cattle in the areas adjacent to the national park, was washed away, and had not been repaired at the time of the outbreak and that buffaloes were observed in the farming areas.

The outbreak occurred in the buffer zone without vaccination and animals were therefore fully susceptible to FMD infection. Although the first cases were found on 1 February 2001, the age of lesions on certain farms suggested that the outbreak had been ongoing for some time prior to that (E. Dyason, personal communication 2001). This could explain why a variant $(S A R / 1 / 01)$ was found on the farm Orinoco at Day 1. After diagnosing the outbreak, cattle were vaccinated during the weeks of 5 February and 5 March 2001 with a trivalent vaccine containing SAT-1, SAT-2 and SAT-3 strains. Therefore, all the isolates acquired between Days 1-6 were most probably from unvaccinated animals and no immune pressure was present. The vaccination cover at Craigieburn was limited since the area is mountainous and it was difficult to find the animals during the vaccination campaigns. It was therefore not surprising when fresh lesions were found at Day 111 (22 May 2001), most probably in unvaccinated animals (information kindly supplied by E. Dyason). Although no samples were characterized between Days 6 and 111, it is clear that the disease had been spreading between farms in the intervening period. The antigenic relationship of the outbreak virus with the vaccine was acceptable with r1-values of 0.4 and 0.35 with the two vaccine strains, respectively (J.J. Esterhuysen, personal communication 2002). It was previously shown that a SAT-1 vaccine with similar r1-values to the outbreak strain protected pigs from needle infection (Cloete, Dungu, Van Staden, Ismail-Cassim \& Vosloo 2008). There is therefore no reason to believe that the vaccine was not protective and the outbreak was controlled using vaccination and movement restrictions. The last clinical cases were observed on 30 May 2001. 
The 11 cattle outbreak isolates in this study accumulated 12 independent mutations (or changes at $1.85 \%$ of sequenced sites) (Fig. 3) over 4 months, which is rapid compared to two previous studies of genetic change in buffaloes. Vosloo et al. (1996) showed a substitution rate of $1.64 \%$ per year over a similar genetic region for a SAT-2 virus in carrier buffaloes and Vosloo et al. (2007) estimated a rate of $1.1 \%$ per year in an outbreak of SAT- 1 in buffalo that also led to the establishment of a carrier state. It is not known whether FMDV might evolve faster in cattle than buffaloes, or whether the faster rate of change observed in this study might have arisen as a result of vaccine induced selection pressure. It may also indicate that rates increase during transmission events compared to sequential isolates from carrier animals. The proportion of these substitutions that were non-synonymous is comparable between this study, 5/12, versus 15/25 in Vosloo et al. (1996). Interestingly, two of the observed non-synonymous changes (pos 135 in SAR/1/01 and 201 in SAR/6/01) are at sites previously identified to be subject to positive selection (Haydon et al. 2001a). When a separate $d_{n}: d_{s}$ ratio is estimated for branches of the phylogeny associated with the recent outbreak in cattle, our analysis revealed it to be significantly higher (by a factor of 4) compared to that arising over the rest of the phylogeny. Such an increase may have occurred as a result of the change of host (from buffalo to cattle), or the presence of vaccine selection, but it may also have arisen as a result of the different time-scales over which viral isolates were collected (111 days versus 13 years).

All the isolates in this study were first propagated on cell culture to obtain sufficient material for amplification and sequencing (Table 1). This could have led to selection of variants that are better adapted to cell culture growth and could have an impact on the results. However, all isolates were subjected to the same regime of being isolated initially on one passage of primary pig kidney cells, while SAR/1/01, $S A R / 7 / 01$ and $S A R / 10 / 01$ were also passaged once on IBRS-2 cells and SAR/11/01 was passaged twice on these cells. No nucleotide changes specific to the viruses passaged on IBRS-2 were observed (results not shown) and the passage history should therefore not influence the results of this study. Three of the amino acid changes are in known antigenic regions, SAR/1/01 at position 135 within the GH loop and SAR/6/01 (position 201) and SAR/8/01 (position 211) within the C-terminal region. We have not investigated antigenic differences using these cell passaged viruses to determine whether any of the changes lead to new antigenic variants. It was previously shown that genetic and antigenic changes could occur after cell passage but that the virus could also be remarkably stable over many cell passages (Domingo, Dávila \& Ortín 1980; Gonzalez, Saiz, Laor \& Moore 1991; Meyer, Pacciarini, Hilyard, Ferrari, Vakharia, Donini, Brocchi \& Molitor 1994).

This study has demonstrated that nucleotide substitutions can arise sufficiently quickly in the 1D gene of FMDV and that genetic data can provide high resolution information on the disease transmission between farms. Information of this sort has high potential value in identifying elusive transmission routes of disease.

\section{ACKNOWLEDGEMENTS}

We honour Billy Phologane who sadly passed away before the paper could be published. We want to express our sincere gratitude to Dr Edwin Dyason for providing the field information for this paper and for critically reading the manuscript. Mr Jan Esterhuysen provided the r1-values of the outbreak isolate.

\section{REFERENCES}

BASTOS, A.D.S. 1998. Detection and characterisation of footand-mouth disease virus in sub-Saharan Africa. Onderstepoort Journal of Veterinary Research, 65:37-47.

BASTOS, A.D., ANDERSON, E.C., BENGIS, R.G., KEET, D.F., WINTERBACH, H.K. \& THOMSON, G.R. 2003a. Molecular epidemiology of SAT3-type foot-and-mouth disease. Virus Genes, 27:283-90.

BASTOS, A.D., HAYDON, D.T., FORSBERG, R., KNOWLES, N.J., ANDERSON, E.C., BENGIS, R.G., NEL, L.H. \& THOMSON, G.R. 2001. Genetic heterogeneity of SAT-1 type footand-mouth disease viruses in southern Africa. Archives of Virology, 146:1537-51.

BASTOS, A.D., HAYDON, D.T., SANGARE, O., BOSHOFF, C.I., EDRICH, J.L. \& THOMSON, G.R. 2003b. The implications of virus diversity within the SAT 2 serotype for control of footand-mouth disease in sub-Saharan Africa. Journal of General Virology, 84:1595-606.

BECK, E. \& STROHMAIER, K. 1987. Subtyping of European foot-and-mouth disease virus strains by nucleotide sequence determination. Journal of Virology, 61:1621-1629.

BOOM, R., SOL, C.J., SALIMANS, M.M.M., JANSEN, C.L., WERTHEIM-VAN DILLEN, P.M.E. \& VAN DER NOORDAA, J. 1990. Rapid and simple method for purification of nucleic acids. Journal of Clinical Microbiology, 28:495-503.

BROOKSBY, J.B. 1982. Portraits of viruses: foot-and-mouth disease virus. Intervirology, 18:1-23.

BRÜCKNER, G.K., VOSLOO, W., DU PLESSIS, B.J.A., KLOECK, P.E.L.G., CONNOWAY, L., EKRON, M.D., WEAVER, D.B., DICKASON, C.J., SCHREUDER, F.J., MARAIS, T. \& MOGAJANE, M.E. 2002. Foot and mouth disease: the experience in South Africa. Revue Scientifique et Technique de I'OIE, 21:751-764. 
CALLENS, M. \& DE CLERCQ, K. 1997. Differentiation of the seven serotypes of foot-and-mouth disease virus by reverse transcriptase polymerase chain reaction. Journal of Virological Methods, 67:35-44.

CLEMENT, M., POSADA, D. \& CRANDELL, K.A. 2000. TCS: a computer program to estimate gene genealogies. Molecular Ecology, 9:1657-1659.

CLOETE, M., DUNGU, B., VAN STADEN, L.I., ISMAIL-CASSIM, N. \& VOSLOO, W. 2008. Evaluation of different adjuvants for foot-and-mouth disease vaccine containing all the SAT serotypes. Onderstepoort Journal of Veterinary Research, 75:1731.

CONDY, J.B., HEDGER, R.S., HAMBLIN, C. \& BARNETT, I.T.R. 1985. The duration of the foot-and-mouth disease carrier state in African buffalo (i) in the individual animal and (ii) in a free-living herd. Comparative Immunology, Microbiology and Infectious Diseases, 8:259-265.

DIEZ, J., MATEU, M.G. \& DOMINGO, E. 1989. Selection of antigenic variants of foot-and-mouth disease virus in the absence of antibodies, as revealed by an in situ assay. General Virology, 70:3281-9.

DOMINGO, E., DÁVILA, M. \& ORTíN, J. 1980. Nucleotide sequence heterogeneity of the RNA from a natural population of foot-and-mouth disease virus. Gene, 11:333-46.

DRAKE, J.W. 1993. Rates of spontaneous mutations among RNA viruses. Proceedings of the National Academy of Science, USA, 90:4171-75.

DRAKE, J.W. \& HOLLAND, J.J. 1999. Mutation rates among RNA viruses. Proceedings of the National Academy of Science, USA, 96:13910-13913.

FARES, M.A., MOYA, A., ESCARMIS, C., BARANOWSKI, E., DOMINGO, E. \& BARRIO, E. 2001. Evidence for positive selection in the capsid protein-coding region of the foot-andmouth disease virus (FMDV) subjected to experimental passage regimens. Molecular Biology and Evolution, 18:10-21.

GEBAUER, F., DE LA TORRE, J.C., GOMES, I., MATEN, M.G., BARAHONA, H., TIRABOSHI, B., BERGMAN, I., DE MELLO, P.A. \& DOMINGO, E. 1988. Rapid selection of genetic and antigenic variants of foot-and-mouth disease during persistence in cattle. Virology, 62:2041-2049.

GONZALEZ, M.J., SAIZ, J.C., LAOR, O. \& MOORE, D.M. 1991. Antigenic stability of foot-and-mouth disease virus variants on serial passage in cell culture. Journal of Virology, 65: 3949-3953.

HARLEY, E.H. 2001. DAPSA. DNA and protein sequence analysis, version 4.91. Department of Chemical Pathology, University of Cape Town, South Africa.

HASEGAWA, M., KISHINO, H. \& YANO, T. 1985. Dating of the human-ape splitting by a molecular clock of mitochondrial DNA. Journal of Molecular Evolution, 22:160-174.

HAYDON, D.T., BASTOS, A., SAMUEL, A. \& KNOWLES, N. 2001a. Evidence for positive selection in foot-and-mouthdisease-virus capsid genes from field isolates. Genetics, 157: $7-15$.

HAYDON, D.T., SAMUEL, A.R. \& KNOWLES, N.J. 2001b. The generation and persistence of genetic variation in foot-andmouth disease virus. Preventative Veterinary Medicine, 51: 111-124.

HOLLAND, J.J., SPINDLER, K., HORODYSKI, F., GRABEU, E., NICHOL, S. \& VANDE POL, S. 1982. Rapid evolution of RNA genomes. Science, 215:1577-1585.

HUNTER, P. 1998. Vaccination as a means of control of foot-andmouth disease in sub-saharan Africa. Vaccine, 16:261-264.
KITSON, J.D., MCCAHON, D. \& BELSHAM, G.J. 1990. Sequence analysis of monoclonal antibody resistant mutants of type $O$ foot and mouth disease virus: evidence for the involvement of the three surface exposed capsid proteins in four antigenic sites. Virology, 179:26-34.

MARTIN, M.J., NUNEZ, J.I., SOBRINO, F. \& DOPAZO, J. 1998. A procedure for detecting selection in highly variable viral genomes: evidence of positive selection in antigenic regions of capsid protein VP1 of foot-and-mouth disease virus. Journal of Virological Methods, 74:215-21.

MASON, P.W., GRUBMAN, M.J. \& BAXT, B. 2003. Molecular basis of pathogenesis of FMDV. Virus Research, 91:9-32.

MATEU, M.G., CAMARERO, J.A., GIRALT, E., ANDREU, D. \& DOMINGO, E. 1995. Direct evaluation of the immunodominance of a major antigenic site of foot-and-mouth disease virus in a natural host. Virology, 206:298-306.

MATEU, M.G., MARTINEZ, M.A., ROCHA, E., ANDREU, D., PAREJO, J., GIRALT, E., SOBRINO, F. \& DOMINGO, E. 1989. Implications of a quasispecies genome structure: effect of frequent, naturally occurring amino acid substitutions on the antigenicity of foot-and-mouth disease virus. Proceedings of the National Academy of Science, USA, 86:5883-5887.

MEYER, R.F., PACCIARINI, M., HILYARD, E.J., FERRARI, S., VAKHARIA, V.N., DONINI, G., BROCCHI, E. \& MOLITOR, T.W. 1994. Genetic variation of foot-and-mouth disease virus from field outbreaks to laboratory isolation. Virus Research, 32:299-312.

SAHLE, M., DWARKA, R.M., VENTER, E.H \& VOSLOO, W. 2007a. Comparison of SAT-1 foot-and-mouth disease virus isolates obtained from East Africa between 1971 and 2000 with viruses from the rest of sub-Saharan Africa. Archives of Virology, 152:797-804.

SAHLE, M., DWARKA, R.M., VENTER, E.H. \& VOSLOO, W. $2007 \mathrm{~b}$. Study of the genetic heterogeneity of SAT-2 foot-andmouth disease virus in sub-Saharan Africa with specific focus on East Africa. Onderstepoort Journal of Veterinary Research, 74:289-299.

SALT, J.S., SAMUEL, A.R. \& KITCHING, R.P. 1996. Antigenic analysis of type $O$ foot-and-mouth disease virus in the persistently infected bovine. Archives of Virology, 141:14071421.

SANGARE, O., BASTOS, A.D.S., MARQUARDT, O., VENTER, E.H., VOSLOO, W. \& THOMSON, G.R. 2001. Molecular epidemiology of serotype $O$ foot-and-mouth disease virus with emphasis on West and South Africa. Virus Genes, 22:343349.

STAVE, J.W., CARD, J.L., MORGAN, D.O. \& VAKHARIA, V.N. 1988. Neutralization sites of type O1 foot-and-mouth disease virus defined by monoclonal antibodies and neutralizationescape virus variants. Virology, 162:21-29.

SWOFFORD, D.L. 2001. PAUP*. Phylogenetic analysis using parsimony ("and other methods). Version 4.0b8. Sunderland, Massachusetts: Sinauer Associates.

TEMPLETON, A.R., CRANDALL, K.A. \& SING, C.F. 1992. A cladistic analysis of phenotypic associations with haplotypes inferred from restriction endonuclease mapping and DNA sequence data. III. Cladogram estimation. Genetics, 132:619633.

THOMSON, G.R. \& BASTOS, A.D.S. 2004. Foot-and-mouth disease, in Infectious diseases of livestock, $2^{\text {nd }}$ ed., edited by J.A.W. Coetzer \& R.C. Tustin. Cape Town: Oxford University Press Southern Africa.

VOSLOO, W., DE KLERK, L.M., BOSHOFF, C.I., BOTHA, B., DWARKA, R.M., KEET, D. \& HAYDON, D.T. 2007. Characterisation of a SAT-1 outbreak of foot-and-mouth disease 
in captive African buffalo (Syncerus caffer): clinical symptoms, genetic characterisation and phylogenetic comparison of outbreak isolates. Veterinary Microbiology, 120:226-240.

VOSLOO, W. \& THOMSON, G.R. 2004. Natural habitats in which foot-and-mouth disease viruses are maintained, in Foot-andmouth disease: current perspectives, edited by E. Domingo \& F. Sobrino, Great Britain: Horizon Bioscience.

VOSLOO, W., BASTOS, A.D.S., MICHEL, A. \& THOMSON, G.R. 2001. Tracing movement of African buffalo in southern Africa. OIE Scientific and Technical Review, 20:630-639.

VOSLOO, W., BASTOS, A.D., KIRKBRIDE, E., ESTERHUYSEN, J.J., JANSE VAN RENSBURG, D., BENGIS, R.G., KEET,
D.F. \& THOMSON, G.R. 1996. Persistent infection of African buffalo (Syncerus caffer) with SAT-type foot-and-mouth disease viruses: rate of fixation of mutations, antigenic change and interspecies transmission. Journal of General Virology, 77:1457-1467.

VOSLOO, W., BASTOS, A.D.S. \& BOSHOFF, K. 2006. Retrospective genetic analysis of SAT-1 type foot-and-mouth disease outbreaks in southern Africa. Archives of Virology, 151: 285-298.

YANG, Z. 1997. PAML: a program for package for phylogenetic analysis by maximum likelihood. CABIOS, 15:555-556. 